\title{
Trace Metals in the Columbia River Estuary Following the 18 May 1980 Eruption of Mount St. Helens ${ }^{1}$
}

\author{
Gerhardt F. Riedel, ${ }^{2,4}$ Stephanie L. Wilson, ${ }^{3,4}$ And R. L. Holton ${ }^{4}$
}

\begin{abstract}
Dissolved and suspended concentrations of cadmium, copper, iron, manganese, nickel, lead, and zinc were measured in the Columbia River Estuary following the 18 May 1980 eruption of Mount St. Helens. Soluble concentrations of these trace elements were not substantially elevated by the influx of volcanic ash and mud into the estuary during this period, except for somewhat higher than usual concentrations of manganese and copper. A laboratory experiment indicates that manganese leached from volcanic debris in fresh water and in the transition from fresh to slightly saline water probably caused the elevated $\mathrm{Mn}$ concentrations. Copper in solution may also have been enhanced slightly by leaching from the material into fresh water.
\end{abstract}

THE ERUPTION OF MOUNT ST. HELENS on 18 May 1980 sent immense volumes of volcanic ash eastward over much of the continental United States and sent large mudflows of volcanic ash and other debris into the Toutle, Cowlitz, and Columbia rivers. Immediately after the eruption and the consequent flow of mud and ash down the Columbia River system there was concern that trace metals released from the ash might have toxic effects on organisms in the estuary. This paper explores the impact of this event on certain trace metal concentrations in the Columbia River Estuary during the period from 21 to 30 May 1980.

\section{METHODS}

\section{Sample Collection}

Water samples were collected from six stations in the Columbia River Estuary (Figure 1) during the period 21-30 May 1980 by

\footnotetext{
${ }^{1}$ Harbor Branch Contribution no. 393. Partial support for this study was provided by the Columbia River Estuary Data Development Program contract 79-13. Manuscript accepted 9 July 1984.

${ }^{2}$ Present address: Harbor Branch Institution, Inc., Rural Route 1 Box 196-A, Fort Pierce, Florida 33450.

${ }^{3}$ Present address: Department of Environmental Regulation, 3426 Bills Road, Jacksonville, Florida 33207.

${ }^{4}$ College of Oceanography, Oregon State University, Corvallis, Oregon 97331.
}

holding an acid-rinsed polyethylene bottle under water with a polyethylene gloved hand. These samples were filtered through acidrinsed $0.4 \mu \mathrm{m}$ Nuclepore filters, and the filters were saved in acid-cleaned polypropylene test tubes for analysis of the particles. The water samples were acidified with $1.0 \mathrm{ml}$ of Ultrex nitric acid to prevent adsorptive losses prior to return to the laboratory (Subramanian et al. 1978), and then frozen until analysis (Pellenbarg and Church 1978). At most sites replicate samples were taken. Our sampling probably selected against high values of seston because all but one of our sampling sites were in sheltered environments, rather than in active channels. However, because of the short residence time of water in the estuary, and rapid mixing by tidal currents and winds, we believe that the soluble concentrations we found fairly represent the entire estuary.

\section{Soluble Trace Metal Analysis}

Concentration of the water samples prior to analysis involved modifications of the Chelex100 technique of Riley and Taylor (1968). Organic compounds in the water which might prevent concentration of trace metals by Chelex-100 were digested with potassium persulfate (Evans et al. 1977). We found that this digestion also oxidized soluble divalent manganese in the sample to particulate 


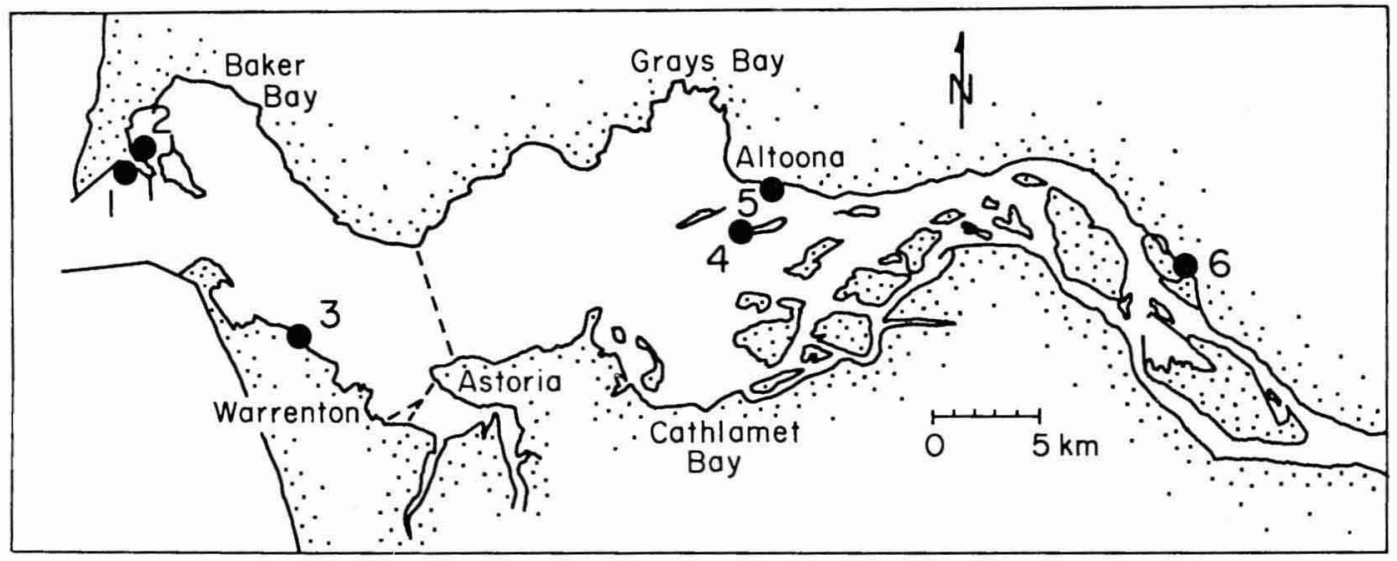

Figure 1. Sampling locations in the Columbia River Estuary.

manganese dioxide, which is not chelated by Chelex-100. Therefore, to insure recovery of $\mathrm{Mn}$ the water samples were then treated with $5 \mathrm{ml}$ of 5 percent $\mathrm{W} \mathrm{V}^{-1}$ hydroxylamine $\mathrm{HCl}$ at $100^{\circ} \mathrm{C}$ prior to neutralization and concentration. Interfering cations also chelated by the resin were removed with an ammonium acetate rinse (Kingston et al. 1978). Blanks were prepared by passing $50 \mathrm{ml}$ of sample water that had been previously extracted through a Chelex-100 column. All reagents added to samples were re-added, and these blank samples were concentrated on Chelex-100 columns as samples. Four blank samples were run with each group of samples.

\section{Particulate Trace Metal Analysis}

The filters with the seston were digested by the $\mathrm{HNO}_{3}-\mathrm{HF}$ method of Evans et al. (1977). After digestion the residue was dissolved in $5.0 \mathrm{ml}$ of 12.5 percent $\mathrm{V} \mathrm{V}^{-1}$ Ultrex nitric acid. Some of each sample, $3 \mathrm{ml}$, was diluted with quartz distilled water and U1trex nitric acid to make a $25 \mathrm{ml}$ sample of 2 percent nitric acid for analysis by internally coupled plasma emission spectrophotometry (ICP). The remaining $2 \mathrm{ml}$ was used for analysis by flame atomic absorption spectrophotometry (AA) and flameless atomic absorption spectrophotometry (FAA). Blanks were prepared by passing filtered seawater through acid-rinsed Nuclepore filters, and digesting these filters as outlined for samples. Blank values and lower limits of detection for all analytical procedures are shown in Table 1. Lower limits of detection were estimated from the number of replicate blanks, the standard deviation of the blanks, and the number of replicate samples. Blank values for trace metals in solution were based on a concentration factor of $20: 1$, and blank values for seston trace metals based on a concentration factor of $100: 1$. Actual concentration factors were in some cases less due to the amount of water filtered. This has been allowed for in the assignment of the overall lower limits of detection.

Because the filters were acid washed in the field, the filters could not be preweighed. The particulate digestion also partially digested the filters, so measurements of suspended solids by difference were not possible with these samples. To estimate the weight of seston we measured aluminum in the seston, and assumed $\mathrm{Al}$ to be in approximately constant composition at $88.4 \mathrm{mg}-(\mathrm{g} \text { ash })^{-1}$ (the mean value of Fruchter et al. 1980) and that the suspended solids were 100 percent volcanic ash. The results of the analysis generally support this assumption.

Analyses by ICP were carried out on an Applied Research model Q137. Analyses by AA were made with a Varian AA5R with an airacetylene flame. The Varian AA5R with a CRA 60 carbon rod atomizer was used for the analyses by FAA. All samples were calibrated against standard series in the same concentration of nitric acid. Background absorption 


\section{TABLE 1}

Method of ANalysis, Blanks, and Estimated Lower Limits of Defection for the Elements Measured

\begin{tabular}{lcc}
\hline \hline $\begin{array}{l}\text { ELEMENT } \\
\text { sample type } \\
\text { (method) }\end{array}$ & $\begin{array}{c}\text { BLANK } \pm \text { s.D. } \\
\left(\mu \mathrm{g} \mathrm{liter}^{-1}\right)\end{array}$ & $\begin{array}{c}\text { LOWER LIMIT OF } \\
\text { DETECTION } \\
\left(\mu \mathrm{g} \mathrm{liter}^{-1}\right)\end{array}$ \\
\hline $\mathrm{Al}$ & & \\
$\quad$ seston (ICP) & $50 \pm 10$ & 50.0 \\
$\mathrm{Mn}$ & & 0.3 \\
$\quad$ solution (ICP) & $0.085 \pm 0.0575$ & 1.0 \\
$\quad$ seston (AA) & $0.15 \pm 0.20$ & \\
$\mathrm{Fe}$ & & 0.5 \\
$\quad$ solution (ICP) & $0.325 \pm 0.096$ & 2.0 \\
$\quad$ seston (ICP) & $0.280 \pm 0.40$ & 1.0 \\
$\mathrm{Ni}$ & & 0.2 \\
$\quad$ solution (FAA) & $0.00 \pm 0.25$ & \\
$\quad$ seston (FAA) & $0.025 \pm 0.035$ & 0.1 \\
$\mathrm{Cu}$ & & 2.0 \\
$\quad$ solution (FAA) & $0.11 \pm 0.02$ & 1.0 \\
$\quad$ seston (AA) & $0.25 \pm 0.35$ & 0.3 \\
$\mathrm{Zn} \quad$ solution (ICP) & $0.14 \pm 0.25$ & \\
$\quad$ seston (ICP) & $0.15 \pm 0.05$ & 0.03 \\
$\mathrm{Cd}$ & & \\
$\quad$ solution (FAA) & $0.0045 \pm 0.0064$ & \\
$\quad$ seston (FAA) & $0.0011 \pm 0.0016$ & 0.01 \\
$\mathrm{~Pb}$ & & \\
$\quad$ solution (FAA) & $0.065 \pm 0.053$ & 0.3 \\
$\quad$ seston (FAA) & $0.010 \pm 0.014$ & 0.1 \\
\hline$\quad$ & & \\
\hline
\end{tabular}

for analyses by both AA and FAA was checked with a hydrogen lamp, and no interference was found, except in the case of $\mathrm{Ni}$ in the particulate samples. In these samples it was corrected for by alternate readings of the background and sample absorption.

\section{Leaching of Trace Metals from Mount St. Helens Ash}

Unweathered ash from the 18 May eruption was collected at Castle Creek, Washington (about $3 \mathrm{mi}$ from the crater). This sample was heterogeneous in grain size distribution, ranging from about $1 \mathrm{~mm}$ to clay-sized particles. Five grams of this volcanic ash was added to a Teflon bottle with 1.0 liter of filtered fresh water from the Yaquina River, Oregon. The sample was stirred for $72 \mathrm{~h}$ to simulate the time of passage of the mudflow material to the estuary (actual observed time for the first material to reach the estuary was about two d), then two $50 \mathrm{ml}$ water samples were filtered through $0.8 \mu \mathrm{m}$ Nuclepore filters, acidified with $0.1 \mathrm{ml}$ Ultrex nitric acid, and frozen until concentration by Chelex-100. The particles on the filters were rinsed back into the bottle along with $100 \mathrm{ml}$ of 32 ppt salinity filtered seawater. This cycle was repeated four times with $24 \mathrm{~h}$ of stirring between samplings to simulate the mixing processes in the estuary. The calculated residence time of water in the Columbia River Estuary based on the river flow during this time of the year is 0.5 $2 \mathrm{~d}$ (Neal 1972). However, as much of the mudflow material settled on the bottom of the estuary, a longer contact period was used. For the last cycle $200 \mathrm{ml}$ was filtered, two $50 \mathrm{ml}$ samples were stored, and $200 \mathrm{ml}$ of seawater were added. After concentration by Chelex100 these samples were analyzed for $\mathrm{Mn}, \mathrm{Fe}$, and $\mathrm{Cu}$. A control bottle with no volcanic ash showed no increases in the initial low metal concentrations.

This experiment is an attempt to partially reproduce in the laboratory the events that occurred in the Cowlitz and Columbia rivers and the Columbia River Estuary as a result of the mudflows stemming from the 18 May 1980 eruption. In several respects it must fall short of an ideal scaling down of the actual event. In particular, the material we used for the leaching was fresh volcanic ash, whereas the material in the actual mudflows was a mixture of fresh ash and previously erupted material from the mountain itself, as well as debris from a variety of sources swept up by the mudflows. However, mudflow material unleached by fresh water is a contradiction in terms, and concerns about toxic trace metals centered on the fresh ash. There might also be differences in the chemistry between the waters in the mudflow (melted snow from the summit of Mount St. Helens, and waters from the original Spirit Lake) and the freshwater we used for the leaching experiment, but again this was unavoidable, and should only affect the initial freshwater portion of the leaching experiment.

\section{RESULTS AND DISCUSSION}

Tables 2 and 3 show the concentrations of dissolved and suspended particulate trace 
TABLE 2

Concentrations of Soluble Trace Metals in the Columbia River Estuary Following the Eruption of Mount St. Helens on 18 May 1980

\begin{tabular}{|c|c|c|c|c|c|c|c|c|c|}
\hline DATE & STATION & $\begin{array}{l}\text { SALINITY } \\
\text { (ppt) }\end{array}$ & $\begin{array}{c}\mathrm{CD} \\
\mu \mathrm{g} 1^{-1}\end{array}$ & $\underset{\mu \mathrm{g} \mathrm{1^{-1 }}}{\mathrm{Cu}}$ & $\begin{array}{c}\mathrm{FE} \\
\mu \mathrm{g} 1^{-1}\end{array}$ & $\frac{\mathrm{MN}_{\mu}}{\mu \mathrm{g} 1^{-1}}$ & $\begin{array}{c}\mathrm{NI} \\
\mu \mathrm{g} 1^{-1}\end{array}$ & $\begin{array}{c}\mathrm{PB}_{\mathrm{B}} \\
\mu \mathrm{g} 1^{-1}\end{array}$ & $\frac{\mathrm{ZN}^{-1}}{\mathrm{~g}^{-1}}$ \\
\hline $5 / 21 / 80$ & 3 & 3.3 & 0.08 & 1.4 & 7.9 & 136 & 1.6 & $<0.3$ & 2.3 \\
\hline $5 / 21 / 80$ & 3 & 3.3 & 0.11 & 0.9 & 3.5 & 119 & $<1.0$ & $<0.3$ & $<1.0$ \\
\hline $5 / 22 / 80$ & 3 & 2.6 & 0.05 & 1.1 & 8.9 & 174 & $<1.0$ & $<0.3$ & $<1.0$ \\
\hline $5 / 22 / 80$ & 3 & 2.6 & 0.06 & 1.0 & 6.8 & 167 & $<1.0$ & $<0.3$ & $<1.0$ \\
\hline $5 / 22 / 80$ & 6 & 0.0 & 0.03 & 2.0 & 15.1 & 30 & $<1.0$ & $<0.3$ & 1.8 \\
\hline $5 / 22 / 80$ & 6 & 0.0 & 0.03 & 1.9 & 22.2 & 33 & $<1.0$ & $<0.3$ & 3.3 \\
\hline $5 / 22 / 80$ & 3 & & 0.06 & 0.8 & 6.1 & 14 & $<1.0$ & $<0.3$ & 1.6 \\
\hline $5 / 22 / 80$ & 5 & 0.0 & 0.10 & {$[2.7]^{*}$} & [112.6] & 61 & $<1.0$ & $<0.3$ & 3.0 \\
\hline $5 / 22 / 80$ & 5 & 0.0 & 0.06 & 1.3 & 35.0 & 51 & [24.9] & $<0.3$ & 2.9 \\
\hline $5 / 23 / 80$ & 3 & 1.6 & 0.05 & 1.3 & 16.8 & 72 & 1.2 & $<0.3$ & 6.0 \\
\hline $5 / 23 / 80$ & 3 & 1.6 & {$[0.54]$} & 1.2 & 12.6 & 70 & 1.1 & $<0.3$ & 9.6 \\
\hline $5 / 23 / 80$ & 2 & 4.8 & 0.04 & 0.9 & 12.7 & 67 & $<1.0$ & $<0.3$ & 1.0 \\
\hline $5 / 23 / 80$ & 2 & 4.8 & 0.05 & 0.9 & 16.8 & 99 & $<1.0$ & $<0.3$ & $<1.0$ \\
\hline $5 / 23 / 80$ & 1 & 13.1 & 0.16 & 1.2 & 6.9 & 49 & $<1.0$ & $<0.3$ & 1.9 \\
\hline $5 / 23 / 80$ & 1 & 13.1 & 0.19 & 1.3 & 9.1 & 37 & $<1.0$ & $<0.3$ & 3.5 \\
\hline $5 / 24 / 80$ & 3 & 2.0 & 0.18 & {$[2.8]$} & [29.1] & 29 & 1.0 & $<0.3$ & 1.2 \\
\hline $5 / 24 / 80$ & 3 & 2.0 & 0.03 & 1.3 & 5.4 & 27 & $<1.0$ & $<0.3$ & $<1.0$ \\
\hline $5 / 30 / 80$ & 4 & 0.0 & 0.24 & 1.0 & 31.3 & 8 & $<1.0$ & $<0.3$ & 3.7 \\
\hline $5 / 30 / 80$ & 4 & 0.0 & [1.69] & 1.3 & 39.4 & 8 & $<1.0$ & [3.5] & {$[22.1]$} \\
\hline
\end{tabular}

*Values in brackets [ ] are suspected of resulting from contamination.

TABLE 3

The Concentrations of Suspended Trace Metals in the Columbia River Estuary Following the 18 May 1980 Eruption of Mount St. Helens

\begin{tabular}{|c|c|c|c|c|c|c|c|c|c|c|c|}
\hline DATE & STATIOI & $\begin{array}{l}\text { SALINITY } \\
\text { (ppt) }\end{array}$ & $\begin{array}{c}\mathrm{AL}_{\mathrm{L}} \\
\mathrm{mg} \mathrm{1^{-1 }}\end{array}$ & $\underset{\mu \mathrm{g} 1^{-1}}{\mathrm{CD}}$ & $\underset{\mu \mathrm{g} 1^{-1}}{\mathrm{Cu}}$ & $\begin{array}{c}\mathrm{FE} \\
\mathrm{mg} 1^{-1}\end{array}$ & $\underset{\mu \mathrm{g} 1^{-1}}{\mathrm{MN}_{1}}$ & $\begin{array}{c}\mathrm{N}_{\mathrm{I}} \\
\mu \mathrm{g} 1^{-1}\end{array}$ & $\begin{array}{c}\text { Рв } \\
\mu \mathrm{g} \mathrm{1^{-1 }}\end{array}$ & $\frac{\mathrm{ZN}_{\mathrm{N}}}{\mu \mathrm{g} 1^{-1}}$ & $\begin{array}{l}\text { SESTON } \\
\mathrm{mg} 1^{-1}\end{array}$ \\
\hline $5 / 21 / 80$ & 3 & & 28.2 & 0.02 & 33 & 8.3 & 148 & 8.0 & 3.1 & 22.4 & 319 \\
\hline $5 / 21 / 80$ & 3 & 3.3 & 4.2 & 0.01 & 5 & 1.3 & 27 & 0.9 & 0.8 & 2.6 & 48 \\
\hline $5 / 21 / 80$ & 3 & 3.3 & 5.1 & $<0.01$ & 6 & 1.5 & 27 & 0.6 & 0.7 & 3.1 & 58 \\
\hline $5 / 22 / 80$ & 3 & 2.6 & 8.6 & 0.01 & 10 & 2.5 & 45 & 0.9 & 0.9 & 3.7 & 97 \\
\hline $5 / 22 / 80$ & 3 & 2.6 & 5.7 & $<0.01$ & 6 & 1.6 & 34 & 0.9 & 0.7 & 2.5 & 64 \\
\hline $5 / 22 / 80$ & 6 & 0.0 & 13.6 & 0.03 & 16 & 4.6 & 76 & 1.3 & {$[4.0]^{*}$} & {$[42.2]$} & 154 \\
\hline $5 / 22 / 80$ & 6 & 0.0 & 12.3 & 0.02 & 16 & 4.2 & 74 & 0.9 & 1.2 & 8.0 & 139 \\
\hline $5 / 22 / 80$ & 3 & & 3.6 & $<0.01$ & 4 & 1.1 & 20 & 0.6 & 0.4 & 2.5 & 41 \\
\hline $5 / 22 / 80$ & 5 & 0.0 & 43.2 & 0.05 & 41 & 14.1 & 244 & 12.1 & 5.3 & 25.0 & 489 \\
\hline $5 / 22 / 80$ & 5 & 0.0 & 43.3 & 0.06 & 43 & 13.9 & 252 & 13.7 & 5.0 & 25.1 & 490 \\
\hline $5 / 23 / 80$ & 3 & 1.6 & 7.1 & $<0.01$ & 10 & 2.6 & 43 & 1.0 & 1.0 & 4.9 & 80 \\
\hline $5 / 23 / 80$ & 3 & 1.6 & 7.7 & 0.01 & 10 & 2.7 & 48 & 1.1 & 0.9 & 4.8 & 87 \\
\hline $5 / 23 / 80$ & 2 & 4.8 & 1.7 & $<0.01$ & 2 & 0.6 & 10 & 0.3 & 0.1 & 1.2 & 19 \\
\hline $5 / 23 / 80$ & 2 & 4.8 & 1.5 & $<0.01$ & 2 & 0.5 & 10 & 0.2 & 0.2 & 1.4 & 17 \\
\hline $5 / 23 / 80$ & 1 & 13.1 & 0.8 & $<0.01$ & 1 & 0.3 & 6 & 0.2 & 0.1 & 0.7 & 9 \\
\hline $5 / 23 / 80$ & 1 & 13.1 & 0.9 & $<0.01$ & 1 & 0.3 & 6 & 0.2 & $<0.1$ & 0.7 & 10 \\
\hline $5 / 24 / 80$ & 3 & 2.0 & 5.1 & 0.02 & 7 & 1.8 & 31 & 1.0 & 0.7 & 3.6 & 58 \\
\hline $5 / 24 / 80$ & 3 & 2.0 & 5.4 & 0.01 & 7 & 1.9 & 34 & 0.6 & 0.7 & 3.9 & 61 \\
\hline $5 / 30 / 80$ & 4 & 0.0 & 6.6 & {$[0.06]$} & 7 & 2.3 & 46 & 0.9 & 1.3 & 6.0 & 75 \\
\hline $5 / 30 / 80$ & 4 & 0.0 & 8.5 & [0.11] & 8 & 2.9 & 43 & 1.0 & 1.3 & 7.4 & 96 \\
\hline
\end{tabular}

*Values in brackets [ ] are suspected of resulting from contamination. 
TABLE 4

Comparison of the Range of Reported Values for Soluble Trace Metal Concentrations in the Columbia RIVER ESTUARY

\begin{tabular}{|c|c|c|c|c|c|c|c|}
\hline REFERENCE & $\begin{array}{c}\mathrm{MN}_{\mu \mathrm{g} 1^{-1}}\end{array}$ & $\begin{array}{c}\mathrm{FE}_{\mathrm{E}} \\
\mu \mathrm{g} \mathrm{1^{-1 }}\end{array}$ & $\begin{array}{c}\mathrm{NI} \\
\mu \mathrm{g} \mathrm{1^{-1 }}\end{array}$ & $\underset{\mu \mathrm{g} 1^{-1}}{\mathrm{Cu}}$ & $\begin{array}{c}\mathrm{ZN}_{\mathrm{N}} \\
\mu \mathrm{g} \mathrm{l}^{-1}\end{array}$ & $\begin{array}{c}\mathrm{CD} \\
\mu \mathrm{g} \mathrm{1^{-1 }}\end{array}$ & $\begin{array}{c}\mathrm{PB}_{\mathrm{B}} \\
\mu \mathrm{g} \mathrm{1^{-1 }}\end{array}$ \\
\hline This & $8-174$ & $3.5-35$ & $<1-2$ & $0.8-2.0$ & $<1-8$ & $<0.03-0.19$ & $<0.3$ \\
\hline dd Cutshall, unpubl. & $3-$ & & & 0 & & & \\
\hline $\begin{array}{l}\text { Holton et al. } 1978 \\
\text { Cutshall and Johnson } 1978\end{array}$ & $0.5-78$ & 0.5 & $0.1-$ & $0.09-0.5$ & 0. & $0.01-1.0$ & $0.01-0.09$ \\
\hline Cutshall and Johnson 1978 & $2-41$ & $14-160$ & $<5.0$ & $<2.0$ & $<0.5-2$ & $<0.2$ & $<2.0$ \\
\hline
\end{tabular}

TABLE 5

Comparison of Reported Values for Trace Metal Content of Suspended Particles and Sediments from the Columbia River Estuary with the Values Found in this Study, Mean Continental Crustal Abundance, and Mean Mount St. Helens Volcanic Ash

\begin{tabular}{|c|c|c|c|c|c|c|c|}
\hline $\begin{array}{l}\text { REFERENCE } \\
\quad \text { (material) }\end{array}$ & $\underset{\mathrm{mg} \mathrm{kg}^{-1}}{\mathrm{MN}_{\mathrm{N}}}$ & $\begin{array}{c}\mathrm{FE} \\
\mathrm{g} \mathrm{kg}^{-1}\end{array}$ & $\underset{\mathrm{mg} \mathrm{kg}^{-1}}{\mathrm{NI}^{-1}}$ & $\underset{\mathrm{mg} \mathrm{kg}^{-1}}{\mathrm{Cu}}$ & $\underset{\mathrm{mg} \mathrm{kg}^{-1}}{\mathrm{Zn}_{\mathrm{N}}}$ & $\begin{array}{c}\mathrm{CD} \\
\mathrm{mg} \mathrm{kg}^{-1}\end{array}$ & $\begin{array}{c}\mathrm{PB}_{\mathrm{B}} \\
\mathrm{mg} \mathrm{kg}^{-1}\end{array}$ \\
\hline $\begin{array}{l}\text { This study } \\
\text { (Columbia R. seston) }\end{array}$ & 498 & 28.5 & 7.1 & 89 & 51.6 & 0.14 & 11 \\
\hline Fruchter et al. 1980 & & & & & & & \\
\hline $\begin{array}{l}\text { (Mt. St. Helens ash) } \\
\text { Holton et al. } 1978\end{array}$ & 596 & 33.6 & 15 & 36 & 53.7 & $<3.0$ & 8.7 \\
\hline $\begin{array}{l}\text { Holton et al. } 1978 \\
\text { (Columbia R. sediment) }\end{array}$ & 48 & 3.5 & 4.5 & 1 & 12 & 0.1 & 3 \\
\hline $\begin{array}{l}\text { Cutshall and Johnson } 1978 \\
\text { (Columbia R. seston) }\end{array}$ & 1,580 & 44.1 & & 47 & 350 & & 22 \\
\hline $\begin{array}{l}\text { Taylor } 1964 \\
\text { (mean continental crust) } \\
\text { Heinrichs et al. } 1980\end{array}$ & 950 & 56 & 75 & 55 & & & \\
\hline (mean continental crust) & & & & & 70 & 0.098 & 14.8 \\
\hline
\end{tabular}

metals found in the Columbia River Estuary at the sites numbered in Figure 1. Also shown are the date of collection and the salinity at that site. Values suspected of resulting from contamination are placed in brackets [ ] and were not considered in the discussion or in the regressions between metals and $\mathrm{Al}$ in the seston. Relatively few values for soluble and seston trace metal concentrations in the Columbia River and Columbia River Estuary are available for comparison, but a few that are have been assembled in Tables 4 and 5 .

\section{Soluble Trace Metals}

Soluble Mn ranged from 8 to $170 \mu$ liter $^{-1}$ in the estuary during this period. The Mn distribution in the estuary showed a mid-salinity enhancement, with the highest value $(170 \mu \mathrm{g}$ liter ${ }^{-1}$ ) occurring at a salinity of $2.6 \mathrm{ppt}$ (Fig- ure 2). Mid-estuarine enhancement of $\mathrm{Mn}$ has been observed in a wide variety of estuaries (e.g., Holiday and Liss 1976, Evans et al. 1977, Duinker and Nolting 1978), including the Columbia River (Evans and Cutshall, unpubl. ms.); however, the highest concentrations reported here are about twice the highest values ever reported for the Columbia River Estuary (Table 4).

Soluble Cu ranged from 0.8 to $2.0 \mu \mathrm{g} \mathrm{liter}^{-1}$ in the estuary during this period. Unlike $\mathrm{Mn}$, $\mathrm{Cu}$ showed little deviation from a conservative distribution with salinity, especially when the variation in the freshwater end member is considered (Figure 2). As with Mn, the values reported here are somewhat higher than those previously reported for the Columbia River Estuary (Table 4).

Soluble Fe ranged from 5.7 to $35.5 \mu \mathrm{g}$ liter $^{-1}$. The trend of $\mathrm{Fe}$ with salinity shows 

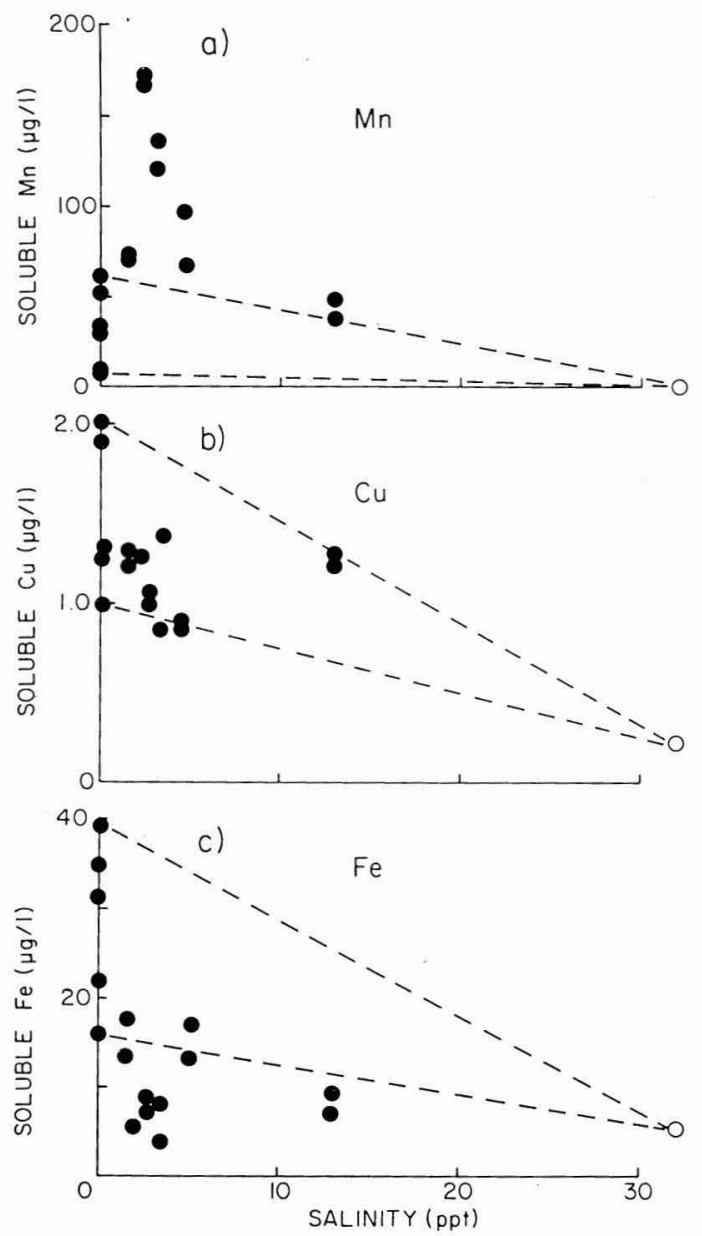

Figure 2. Concentrations of soluble $\mathrm{Mn}, \mathrm{Cu}$, and $\mathrm{Zn}$ in the Columbia River Estuary during the period 21-30 May 1980 plotted as a function of salinity. Dashed lines indicate the maximum and minumum conservative mixing line from the highest and lowest values at the freshwater end member to typical coastal ocean values at 32 ppt salinity.

loss of $\mathrm{Fe}$ from solution in the estuary, a phenomenon observed for $\mathrm{Fe}$ in a variety of estuaries (e.g., Coonley, Baker, and Holland 1971, Boyle et al. 1974, Bewers, Sundby, and Yeats 1974, Holliday and Liss 1976, Evans et al. 1977). The range of Fe concentrations presented here is not unusual for the Columbia River Estuary (Table 4).

Soluble $\mathrm{Cd}, \mathrm{Ni}, \mathrm{Pb}$, and $\mathrm{Zn}$ were in many cases below the limit of detection, and several samples showed evidence of contamination.

\section{Seston Trace Metals}

As estimated by the concentration of suspended particulate aluminum, seston ranged from $10-490 \mathrm{mg} \mathrm{liter}^{-1}$. This agrees with Frey, Lara-Lara, and Small (1983) who reported values of 130 to $638 \mathrm{mg} \mathrm{liter}^{-1}$ with a mean of $353 \mathrm{mg} \mathrm{liter}^{-1}$ during the period 22-24 May 1983. Newcomb and Flagg (1983) speculate that seston in the lower Columbia River immediately after the mudflows from the Toutle and Cowlitz rivers might have exceeded $6 \mathrm{~g} \mathrm{liter}^{-1}$. In addition to suspended particulate material, a very large, but unquantified amount of material may have been carried into the estuary as bed load. Approximately $34 \times 10^{6} \mathrm{~m}^{3}$ of material was reported to have been deposited in the Columbia River by the mudflows from the 18 May eruption, and $38 \times 10^{6} \mathrm{~m}^{3}$ in the Cowlitz River (Schuster 1981). In the estuary itself, a layer of volcanic debris from 0.5 to $11.5 \mathrm{~cm}$ deep, averaging $4.5 \mathrm{~cm}$, was deposited in the shallows (Brzezinski and Holton 1983).

The concentrations of individual elements within the seston were highly correlated, as would be expected with a homogeneous substance. This is shown in Figure $3 a-g$ by the high correlation of each element with $\mathrm{Al}$. The mean elemental composition of Mount St. Helens volcanic ash was also taken from the data of Fruchter et al. (1980), while mean continental crustal abundance of $\mathrm{Al}, \mathrm{Fe}, \mathrm{Mn}$, $\mathrm{Ni}$, and $\mathrm{Cu}$ was taken from Taylor (1964), and the values for mean continental crustal abundance of $\mathrm{Zn}, \mathrm{Cd}$, and $\mathrm{Pb}$ were taken from Heinrichs, Shulz-Dobrick, and Wedepohl (1980). These are shown in Table 5, along with other reported values for elemental composition of Columbia River Estuary seston and sediments. This table shows that the elemental composition of seston from the estuary during this period is nearly identical to the airborne ash, similar to mean crustal abundance, and distinct from previously reported sediments and seston from the Columbia River Estuary.

\section{Leaching of Trace Metals from Mount} St. Helens Ash

Manganese concentration as a function of salinity in the laboratory leaching experiment 

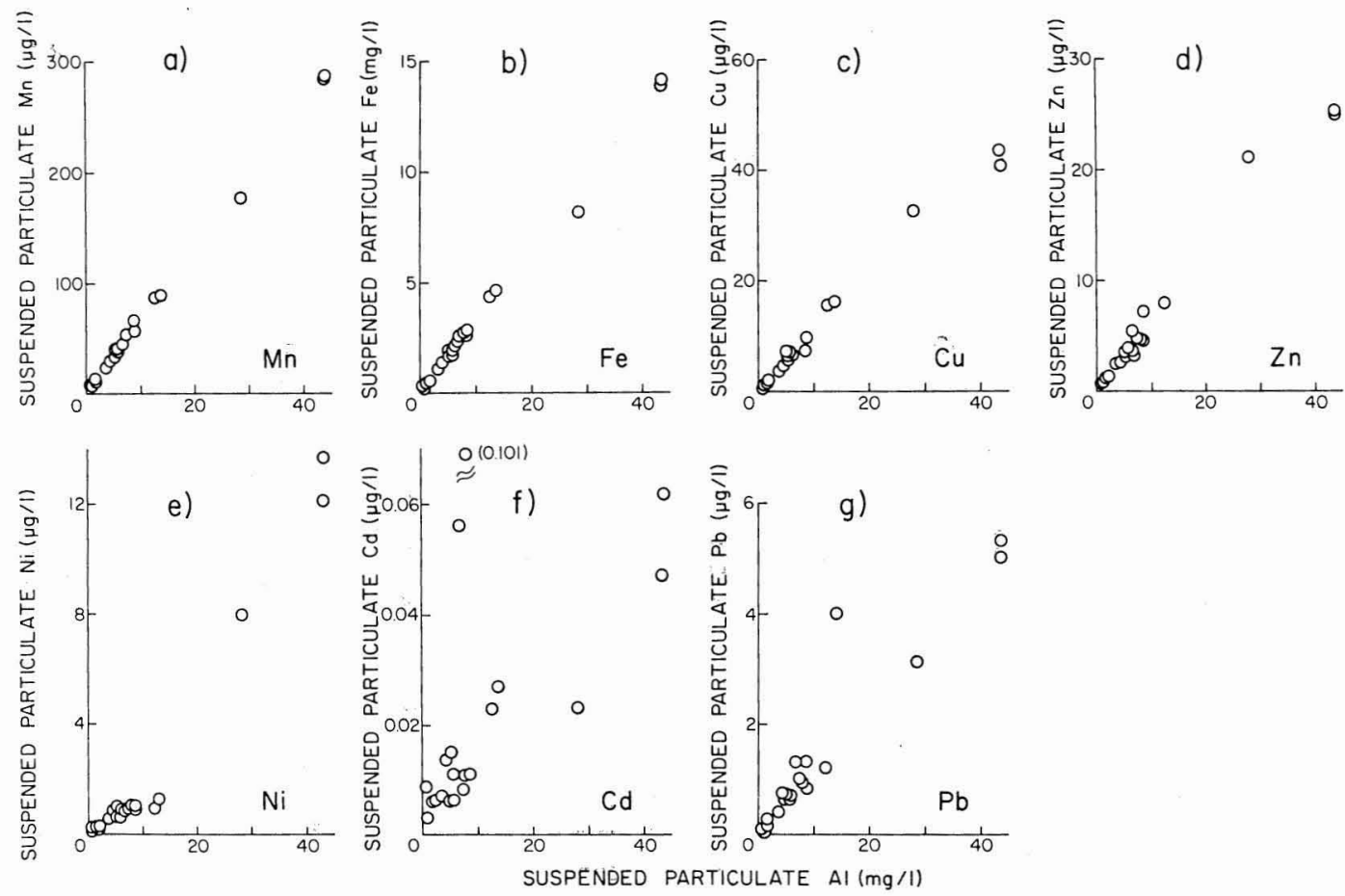

Figure 3. Concentrations of suspended particulate $\mathrm{Mn}, \mathrm{Fe}, \mathrm{Cu}, \mathrm{Zn}, \mathrm{Ni}, \mathrm{Cd}$, and $\mathrm{Pb}$ in the Columbia River Estuary during the period 21-30 May 1980 plotted against suspended particulate $\mathrm{Al}$.

is plotted in Figure $4 a$. There was an initial leaching of $12 \mu \mathrm{g} \mathrm{Mn}$ (g ash) ${ }^{-1}$ over $72 \mathrm{~h}$ in fresh water, an additional $17 \mu \mathrm{g}$ Mn $\left(\mathrm{g}\right.$ ash) ${ }^{-1}$ leached into water of $3.2 \mathrm{ppt}$ salinity, and thereafter dilution and loss of Mn from solution. From these results it is suggestive that Mn was released from Mount St. Helens volcanic ash as it entered fresh water and again when it mixed with slightly saline water. If the lower Columbia River carried as much as $6 \mathrm{~g}$ liter ${ }^{-1}$ volcanic ash during this period, as much as $72 \mu$ g liter $^{-1} \mathrm{Mn}$ could have been present in water of zero salinity from this source alone. If that same concentration of ash came in contact with water of $3.2 \mathrm{ppt}$ salinity, an additional $102 \mu \mathrm{g} \operatorname{liter}^{-1} \mathrm{Mn}$ would have been added. This would almost exactly account for the observed $170 \mu \mathrm{g} \mathrm{liter}^{-1}$ Mn peak at $2.6 \mathrm{ppt}$ salinity in the estuary. In addition to $\mathrm{Mn}$ from volcanic ash, soluble Mn in the Columbia River could be expected to be as much as $80 \mu \mathrm{g} \mathrm{liter}^{-1}$, which would lower the amount of ash required to produce the observed peak to as little as 3 g liter $^{-1}$.
Copper showed an initial leaching of $0.5 \mu \mathrm{g}$ $(\mathrm{g} \text { ash })^{-1}$ in fresh water, and subsequent loss from solution greater than that predicted by dilution alone (Figure 4b). As with $\mathrm{Mn}$, on the order of $6 \mathrm{~g}$ liter $^{-1}$ volcanic ash could explain the concentrations of $\mathrm{Cu}$ found in the estuary, and less if normal concentrations of $\mathrm{Cu}$ of up to $0.6 \mu \mathrm{g} \mathrm{liter}^{-1}$ are considered.

Iron showed no increase upon addition of Mount St. Helens volcanic ash to the fresh or saline water, and in fact, the small concentration of Fe initially measurable in the freshwater used in the experiment was lost from solution.

The amount of $\mathrm{Mn}$ and $\mathrm{Cu}$ lost from the volcanic ash to solution in our leaching experiment were small fractions of those initially present in the ash, about 6 percent for $\mathrm{Mn}$ and 1.4 percent for $\mathrm{Cu}$.

In the Cowlitz and Columbia rivers a total of $72 \times 10^{6} \mathrm{~m}^{3}$ of mudflow material was deposited upstream from the estuary as a result of the 18 May eruption (Schuster 1981); however, the water in contact with this material 

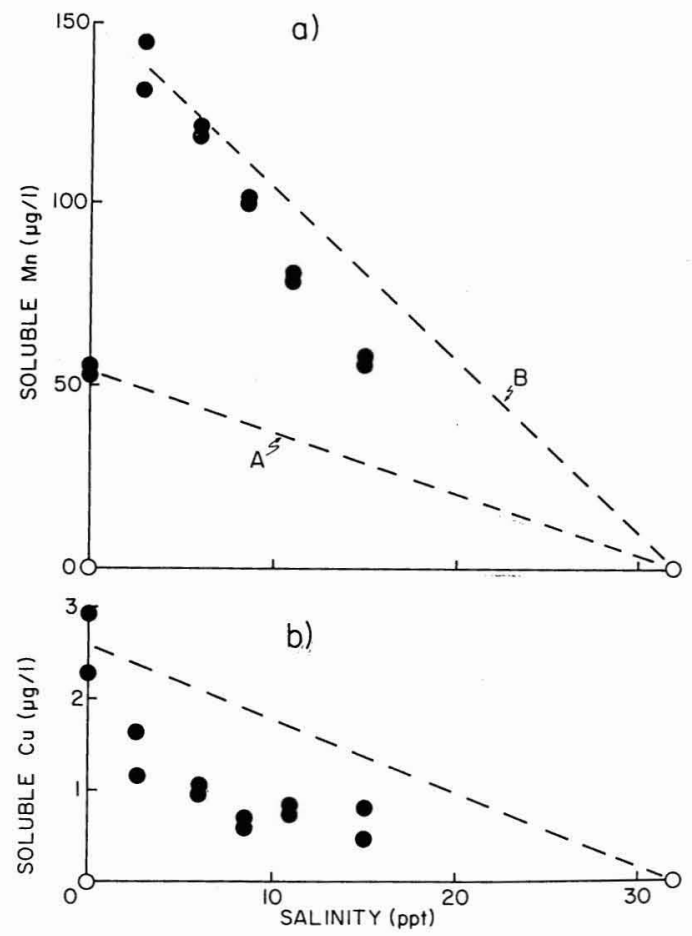

Figure 4. Concentrations of soluble $\mathrm{Mn}$ (a) and $\mathrm{Cu}$ (b) in the laboratory leaching experiment with Mount St. Helens ash. For Mn two theoretical conservative mixing lines are shown by dashed lines, one from the concentration released to freshwater after $72 \mathrm{~h}(A)$, and one from the concentration released to water of $3.2 \mathrm{ppt}$ salinity $(B)$. For $\mathrm{Cu}$ the dashed line shows the theoretical conservative line from the concentration released to freshwater after $72 \mathrm{~h}$.

reached the estuary within $2 \mathrm{~d}$. The flow of the Columbia River during this period was $10.8-12.3 \times 10^{3} \mathrm{~m}^{3} \mathrm{sec}^{-1}$ (U.S. Geological Survey 1980). Assuming an average bulk density of $1.12 \mathrm{~g} \mathrm{~cm}^{-3}$ for the volcanic debris (Sarna-Wojcicki et al. 1981), this leads to an estimate that the waters of the Columbia River had interacted with approximately $40 \mathrm{~g}$ liter ${ }^{-1}$ of volcanic debris.

Although mudflow material was of similar elemental composition to the volcanic ash, it had a much different grain size distribution, ranging from clay size to boulder size (Janda et al. 1981). Also because some of it was previously weathered, it undoubtedly leached less per unit mass in either fresh or saline waters. Nevertheless, leaching of Mn from the large amounts of material in the Cowlitz and Columbia Rivers may account for all of the $\mathrm{Mn}$ and $\mathrm{Cu}$ we found in the estuary. Because of the possible difference in chemical behavior between airborne ash used in our leaching experiment and the actual mudflow material, which was composed of both fresh ash and older material, we are unable to fully evaluate the relative role of fresh versus saline water leaching as a source of excess dissolved material.

\section{CONCLUSIONS}

From the field data and laboratory leaching experiment it appears that mudflows in the Cowlitz and Columbia rivers from the 18 May 1980 eruption of Mount St. Helens, and the consequent high seston load in the Columbia River Estuary, allowed leaching of $\mathrm{Mn}$ and $\mathrm{Cu}$ in fresh and saline waters. Elevated soluble concentrations of $\mathrm{Fe}, \mathrm{Zn}, \mathrm{Ni}, \mathrm{Cd}$, and $\mathrm{Pb}$ were not found, despite high total levels in the seston.

The trace metal concentrations present in the Columbia River Estuary in the period following the eruption of Mount St. Helens posed no serious threat to the estuary. Manganese is not notably toxic, and is present in other estuaries at concentrations greater than those reported here (q.v. Graham, Bender, and Klinkhammer 1976), although this event appears to be unusual for the Columbia River. Copper is inhibitory to marine phytoplankton at concentrations similar to those reported here only in the absence of complex forming organics (Davey, Morgan, and Erikson 1973). In any event, phytoplankton production in the Columbia River Estuary during this period was severely inhibited by lack of light caused by the turbidity from the mudflows (Frey, Lara-Lara, and Small 1983).

\section{ACKNOWLEDGMENTS}

We thank Jerry Wagner and Susan Sherman of the USEPA for the analyses by ICP, Kim Jones for help in sample collection, and Bob Karlin for the fresh volcanic ash. 


\section{LITERATURE CITED}

Bewers, J. M., B. Sundby, and P. A. Yeats. 1974. Trace metals in the waters of the Gulf of St. Lawrence. Can. J. Earth Sci. 11:939-950.

Brzezinski, M. A., and R. L. Holton. 1983. A report on the macroinvertebrates of the Columbia River Estuary found in deposits of volcanic ash from the May 18, 1980 eruption of Mount St. Helens. Estuaries 6:172-175.

Boyle, E., R. Collier, A. T. Dengler, J. M. Edmond, A. C. NG, and R. F. Stallard. 1974. On the chemical mass balance in estuaries. Geochim. Cosmochim. Acta $38: 1719-1728$.

Coonley, L. S., Jr., E. B. BakeR, and H. D. Holland. 1971. Iron in the Mullica River and in Great Bay, New Jersey. Chem. Geol. 7:51-63.

Cutshall, N., and V. G. Johnson. 1978. Inventory and assessment of predisposal physical and chemical conditions. Appendix A in Habitat development field investigations Miller Sands Marsh and upland habitat development site, Columbia River, Oregon. Tech. Rept. D-77-38, Environ. Lab., U.S. Engineers Waterways Experiment Station, Vicksburg, Mississippi. 208 pp.

Davey, E. W., M. J. Morgan, and S. J. ERIKSON. 1973. A biological measurement of the copper complexation capacity of seawater. Limnol. Oceanogr. 18:993-997.

Duinker, J. C., and R. F. Nolting. 1978. Mixing, removal and remobilization of trace metals in the Rhine Estuary. Neth. J. Sea Res. 12:205-223.

Evans, D. W., and N. H. Cutshall. Unpubl. ms. Non-conservation of dissolved copper and manganese in three U.S. estuaries.

Evans, D. W., N. H. Cutshall, F. A. Cross, and D. A. WoLfE. 1977. Manganese cycling in the Newport River Estuary, North Carolina. Estuarine Coastal Mar. Sci. 5:71-80.

Frey, B. F., J. R. Lara-Lara, and L. F. SMALL. 1983. Reduced rates of primary production in the Columbia River Estuary following the eruption of Mt. Saint Helens on
18 May 1980. Estuarine Coastal Shelf Sci. $17: 213-218$.

Fruchter, J. S., D. E. Robertson, J. C. Evans, K. B. Olsen, E. A. Lepel, J. C. Laul, K. H. Abel, R. W. Sanders, P. O. Jackson, N. S. Wogman, R. W. Perkins, H. H. Van Tuyl, R. H. Beauchamp, J. W. Shade, J. L. Daniel, R. L. Erikson, G. A. Sehmel, R. N. Lee, A. V. Robinson, O. R. Moss, J. K. Briant, and W. C. Cannon. 1980. Mount St. Helens ash from the 18 May 1980 eruption: Chemical, physical, minerological, and biological properties. Science 209:1116-1125.

Graham, W. F., M. L. Bender, and G. P. KLINKHAMmer. 1976. Manganese in Narragansett Bay. Limnol. Oceanogr. 21: 665-673.

Heinrichs, H., B. Shulz-Dobrick, and K. H. WEDEPOHL. 1980. Terrestrial geochemistry of $\mathrm{Cd}, \mathrm{Bi}, \mathrm{Tl}, \mathrm{Pb}, \mathrm{Zn}$ and $\mathrm{Rb}$. Geochim. Cosmochim. Acta 44:1519-1533.

HollidAy, L. M., and P. S. Liss. 1976. The behaviour of dissolved iron, manganese, and zinc in the Beaulieu Estuary, S. England. Estuarine Coast. Mar. Sci. $4: 349-353$.

Holton, R. L., N. H. Cutshall, L. I. Gordon, and L. F. SMall. 1978. Water column, primary productivity and sediment studies. Appendix B in Aquatic disposal field investigations, Columbia River disposal site, Oregon. Tech. Rept. D-77-30, U.S. Army Engineer Waterways Experiment Station, Vicksburg, Mississippi. 153 $\mathrm{pp}$.

JANDA, R. J., K. M. ScotT, K. M. Nolan, and H. A. MARTINSON. 1981. Lahar movement, effects and deposits. Pages 461-478 in. The 1980 eruptions of Mount St. Helens, Washington. U. S. Geological Survey Prof. Pap. 1250.

Kingston, H. M., I. L. Barnes, T. J. Brady, T. C. Rains, and M. A. Champ. 1978. Separation of eight transition elements from alkali and alkaline earth elements in estuarine and seawater with chelating resin and their determination by graphite furnace atomic absorption spectrometry. Anal. Chem. 50:2064-2070.

Neal, V. T. 1972. Physical aspects of the 
Columbia River and its estuary. Pages 19-40 in A. T. Pruter, and D. L. Alverson, eds. The Columbia River estuary and adjacent ocean waters. University of Washington Press, Seattle, Washington.

Newcomb, T. W., and T. A. Flagg. 1983. Some effects of Mount St. Helens volcanic ash on juvenile salmon smolts. Mar. Fish. Rev. 45:8-12.

Pellenbarg, R. E., and T. M. Church. 1978. Storage and processing of estuarine water samples for trace metal analysis by atomic absorption spectrophotometry. Anal. Chim. Acta 97:81-86.

Riley, J. P., and D. TAYLOR. 1968. Chelating resins for the concentration of trace metals from seawater and their analytical use in conjunction with atomic absorption spectrophotometry. Anal. Chim. Acta 40:479-485.

Sarna-Wojcicki, A. M., S. Shipley, R. B. WaITT, Jr., D. Dzurisin, and S. Wood. 1981. Areal distribution, thickness, mass, volume, and grain size of airfall ash from the six major eruptions of 1980 . Pages 577-600 in. The 1980 Eruptions of Mount St. Helens, Washington. U. S. Geological Survey Prof. Pap. 1250.

SCHUSTER, R. L. 1981. Effects of the eruptions on civil works and operations in the Pacific northwest. Pages 701-718 in. The 1980 Eruptions of Mount St. Helens, Washington. U. S. Geological Survey Prof. Pap. 1250.

Subramanian, K. S., C. L. Chakarabarti, J. E. Sueiras, and I. S. Maines. 1978. Preservation of some trace metals in samples from natural waters. Anal. Chem. 50:442-448.

TAYLOR, S. R. 1964. Abundance of chemical elements in the continental crust: A new table. Geochim. Cosmochim. Acta 28: 1273-1285.

U.S. Geological Survey. 1980. Pacific Northwest water resources summary. Portland, Oregon. 